\title{
Informacja o zmianach liczby ludności oraz liczby i struktury urodzeń według kolejności
}

Podstawowymi czynnikami determinującymi rozwój ludności są zjawiska ruchu naturalnego, na który składają się: zawieranie małżeństw, urodzenia i zgony. Urodzenia decydują o dodatnim wpływie, czyli o liczbie nowych mieszkańców kraju. Jednocześnie w Polsce nadal znacząca większość dzieci rodzi się w formalnych związkach, co oznacza, że wzrost liczby nowo zawieranych małżeństw może skutkować (w okresie 2-3 lat) wzrostem liczby urodzeń. Z kolei zgony zmniejszają liczebność populacji. Różnica pomiędzy liczbą urodzeń i zgonów określana jest mianem przyrostu naturalnego ludności. Na przyrost rzeczywisty składa się dodatkowo saldo ruchu wędrówkowego ludności.

W końcu 2017 roku liczba ludności Polski wynosiła 38434 tys. osób, czyli o 0,6 tys. więcej niż w 2016 roku. Na każde 100 tys. ludności kraju przybyła 1 osoba, podczas gdy rok wcześniej notowano ubytek ok. 10 osób na 100 tys. mieszkańców. 


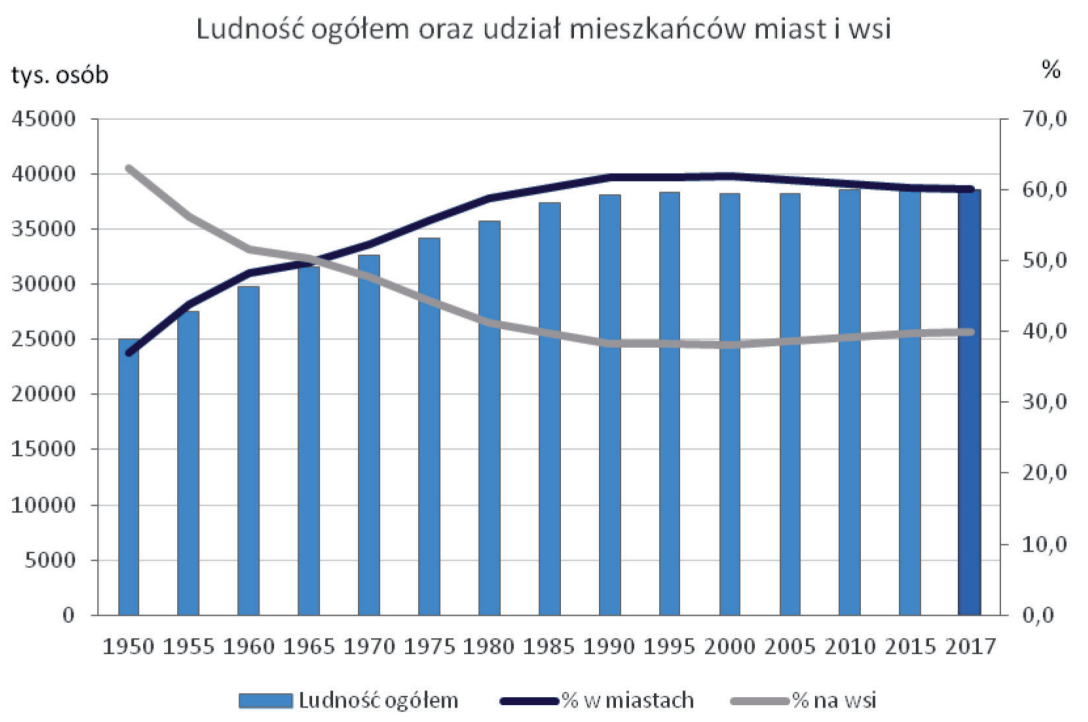

Zmniejszanie liczby mieszkańców Polski jest powodowane głównie spadkiem rozmiarów populacji w miastach; zmniejsza się też jej udział w liczbie ludności ogółem. Z kolei rośnie liczba mieszkańców obszarów wiejskich, w szczególności terenów wokół dużych miast. Przyrost liczby ludności w 2017 roku dotyczył wyłącznie mieszkańców wsi, dla których odnotowano dodatnie wartości przyrostu naturalnego i salda migracji.

Do połowy lat 80 . ubiegłego stulecia notowano istotne roczne przyrosty liczby ludności. Na przełomie lat 80. i 90. tempo przyrostu rzeczywistego populacji było coraz wolniejsze. W okresie od 1997 do 2007 roku obserwowano niewielkie ujemne wartości przyrostu rzeczywistego ludności, w kolejnych kilku latach nieznaczne dodatnie tempo tego przyrostu, a od 2012 roku znów notowano ubytki liczby ludności o małej skali.

Rok 2017 był pierwszym po 5 latach spadku, w którym wystąpił niewielki wzrost rozmiarów populacji mieszkańców Polski. 


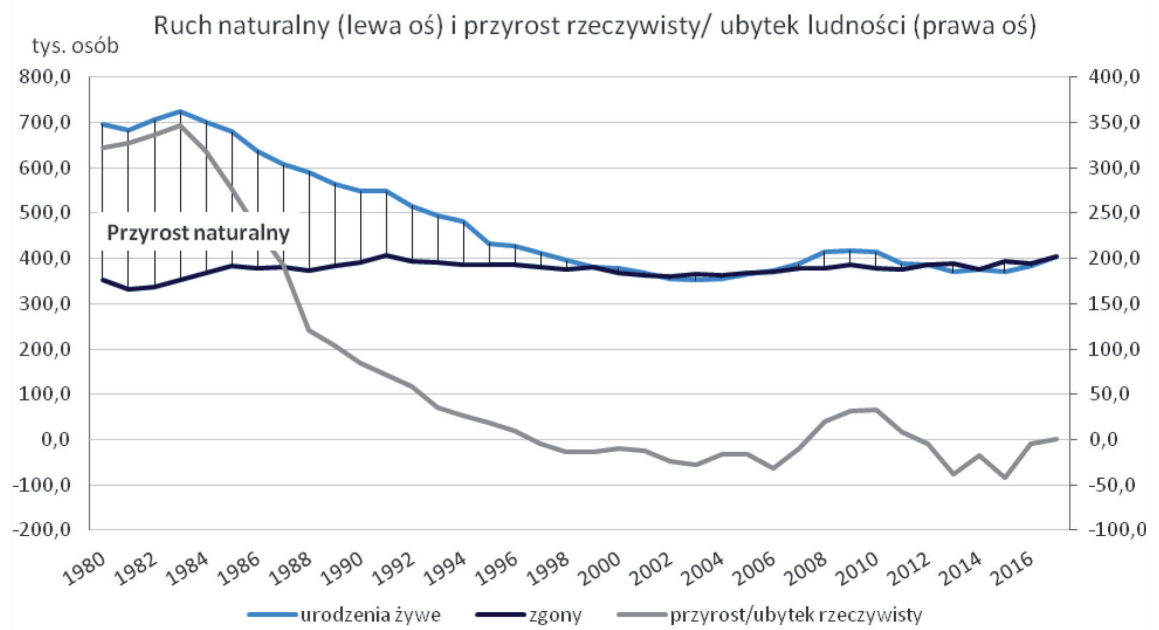

Przyrost naturalny był w 2017 roku ujemny (-0,9 tys.). W miastach liczba zgonów przewyższyła liczbę urodzeń o 11,2 tys., a na wsi odnotowano nadwyżkę urodzeń o 10,3 tys.

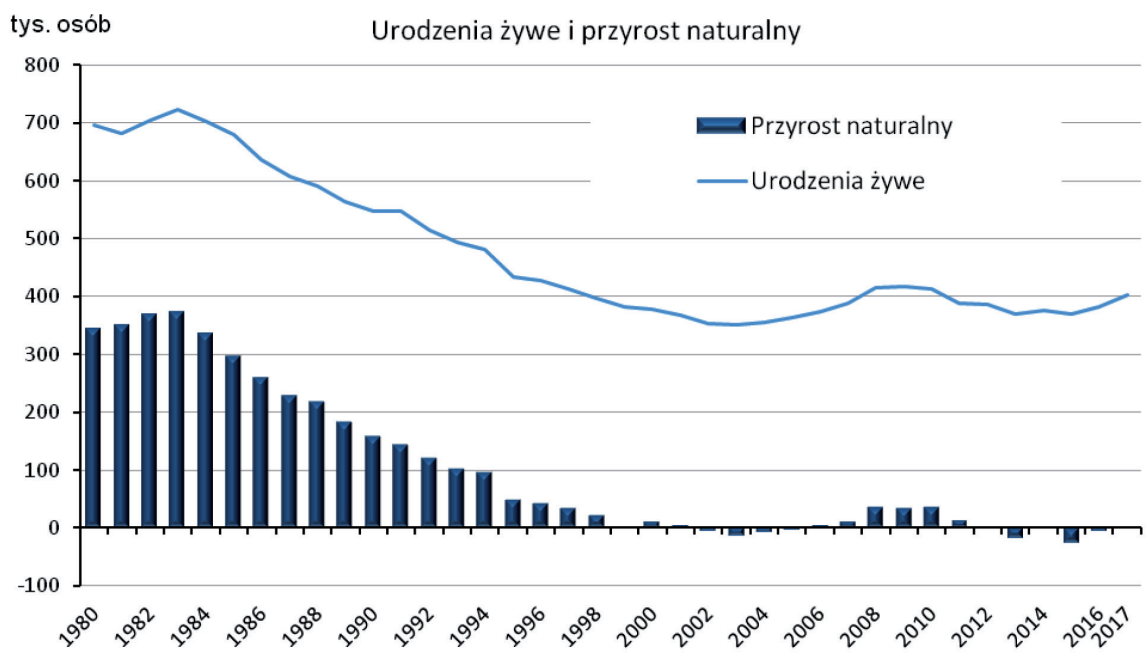

Od ostatniego wyżu demograficznego w 1983 roku wielkość przyrostu naturalnego ludności systematycznie się zmniejszała, przede wszystkim na skutek spadku liczby urodzeń. W latach 2002-2005 obserwowano ubytek naturalny, największy w 2003 roku (nadwyżka liczby zgonów nad urodze- 
niami wyniosła wtedy 14,1 tys.). Od 2006 do 2011 roku przyrost naturalny był dodatni, a w następnych latach notowano znów ujemne wartości (w 2015 roku wystąpił najwyższy ubytek naturalny ludności, tj. 25,6 tys.).

Najważniejszym czynnikiem kształtującym rozmiary i strukturę ludności jest liczba urodzeń. Spadkowy trend po wyżu demograficznym z pierwszej połowy lat 80. trwał aż do 2003 roku, po czym liczba urodzeń rosła do 2009 roku, będąc echem ostatniego wyżu, a w kolejnych latach znów notowano spadek liczby urodzeń.

Od dwóch lat obserwujemy wzrost liczby urodzeń. W 2016 roku urodziło się w Polsce 382,3 tys. dzieci, o 13 tys. więcej w stosunku do poprzedniego roku, a w 2017 roku liczba urodzeń wyniosła 402 tys., tj. więcej o kolejne 20 tys. Współczynnik urodzeń na 1000 ludności zwiększył się do 10,5 promille (9,9 promille w 2016 r.). Odnotowano wzrost wartości współczynnika dzietności.

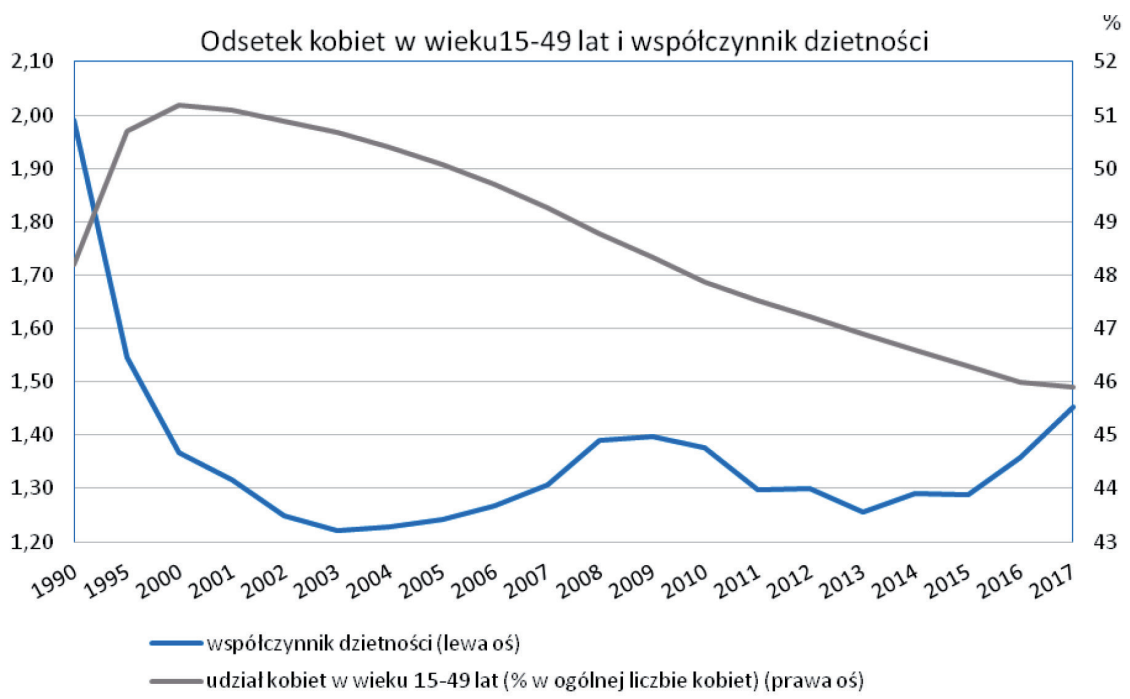

Od wielu lat liczba urodzeń w Polsce nie zapewnia jednak poziomu prostej zastępowalności pokoleń. Najbardziej korzystną sytuację pod tym względem określa współczynnik dzietności na poziomie 210-215 żywo urodzonych dzieci przypadających na 100 kobiet w wieku 15-49 lat. Taką w przybliżeniu wielkość notowano ostatnio w Polsce w 1989 roku. 
W 2017 roku współczynnik dzietności wyniósł 1,45 (na 100 kobiet w wieku rozrodczym przypadało 145 żywo urodzonych dzieci) i był najwyższy od 20 lat. Taka wartość współczynnika jest znacząco mniejsza od wielkości, która mogłaby zapewnić stabilny rozwój demograficzny, jednocześnie perspektywy poprawy tej sytuacji nie są optymistyczne z uwagi na obserwowany spadek liczby kobiet w wieku 15-49 lat. Wykres ilustruje zmiany współczynnika dzietności i udział kobiet w wieku rozrodczym w liczbie ludności ogółem, zmniejszający się od początku bieżącego stulecia.

Natężenie urodzeń jest większe na wsi niż w miastach. Wśród kobiet mieszkających na obszarach wiejskich notuje się wyższy poziom dzietności niż w miastach. Na 100 mieszkanek wsi w wieku 15-49 lat w 2017 roku przypadało 149 urodzeń żywych, a wśród kobiet w miastach - 142 .

Cechą charakterystyczną zmian demograficznych obserwowanych od początku lat 90. XX wieku jest przesuwanie się najwyższej płodności do starszych grup wieku kobiet. Ma to związek z odkładaniem w czasie decyzji o założeniu rodziny, przez co skraca się okres aktywnej prokreacji i zmniejsza szansa na urodzenie przez kobietę większej liczby dzieci.

Płodność kobiet według wieku

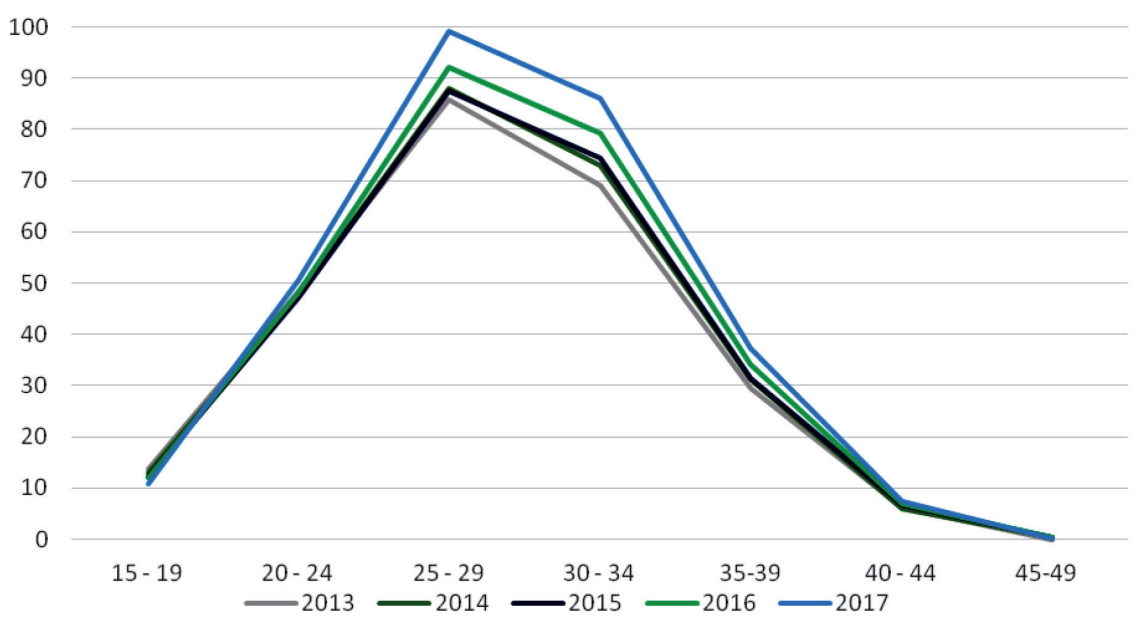

Wykres ilustruje przesunięcie najwyższej płodności z grupy wieku 2024 do 25-29 lat. Jednocześnie znacznie wzrosła płodność kobiet z kolejnej 5-letniej grupy wieku (30-34 lat), co w dużej mierze stanowi efekt realizacji 
odłożonych urodzeń. Zmiany te są powodowane wydłużeniem okresu edukacji oraz dążeniem młodych ludzi do osiągnięcia stabilnej pozycji zawodowej przed podjęciem decyzji o założeniu rodziny. Mediana wieku kobiet rodzących dziecko w 1990 roku wynosiła 26 lat, a w 2017 roku wzrosła do 30 lat.

Obserwowane zmiany natężenia urodzeń według wieku kobiet mają istotny wpływ na kształtowanie się struktury urodzeń według ich kolejności. Wzrost liczby urodzeń w 2016 i w 2017 roku dotyczył przede wszystkim dzieci urodzonych jako drugie, trzecie i dalszej kolejności. W 2017 roku pomimo wzrostu ogólnej liczby urodzeń zmniejszyła się liczba dzieci urodzonych jako pierwsze.

Podczas gdy przeciętna kolejność urodzenia dziecka u matki kształtuje się w ostatnich latach na podobnym poziomie $(1,7-1,8)$, to następuje zmiana w strukturze urodzeń według kolejności. Udział urodzeń pierwszych zmniejszył się na rzecz urodzeń wyższych kolejności (szczególnie drugich).

Urodzenia żywe według kolejności urodzenia dziecka u matki

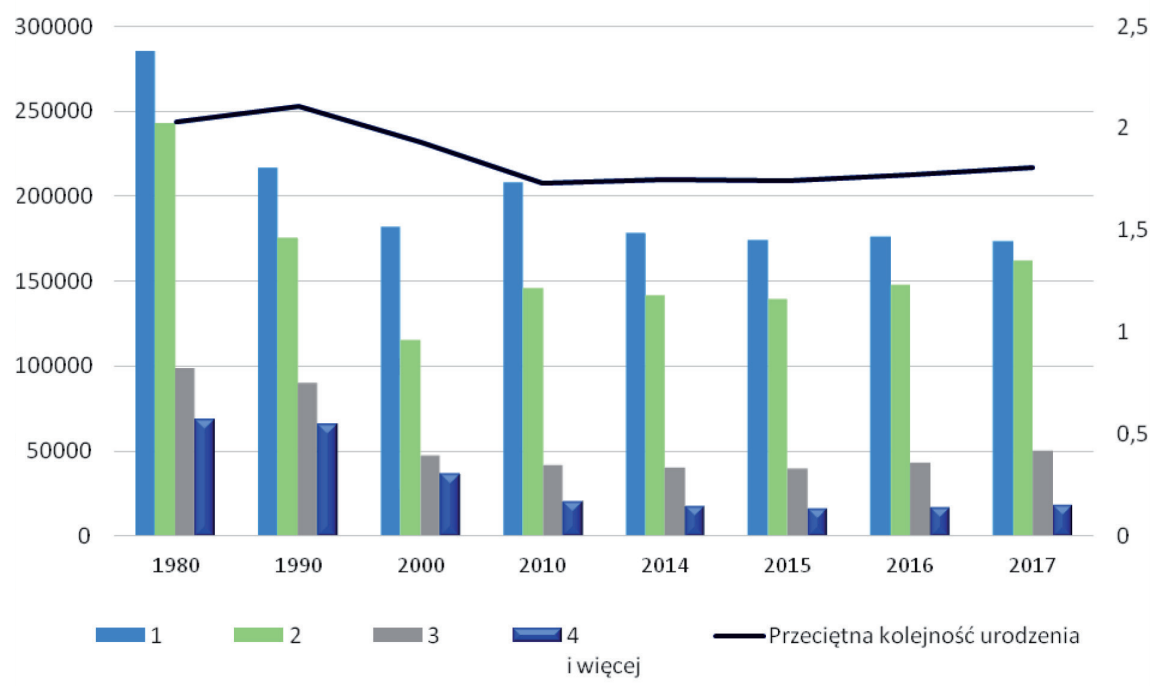

W 2010 roku urodzenia pierwszej kolejności stanowiły połowę wszystkich urodzeń żywych. W kolejnych latach ich udział powoli się zmniejszał i w 2015 roku wynosił 47\%, a w 2016 - 46\%. W 2017 roku odnotowano spadek zarówno liczby, jak i odsetka dzieci urodzonych jako pierwsze w stosunku do poprzedniego roku. Urodzenia pierwszej kolejności stanowiły 
już tylko 43\% urodzeń żywych, natomiast wzrosły liczby i odsetki urodzeń drugich, trzecich, czwartych i kolejnych urodzeń. Udział urodzeń drugiej kolejności zwiększył się w 2017 roku do 40,1\%.

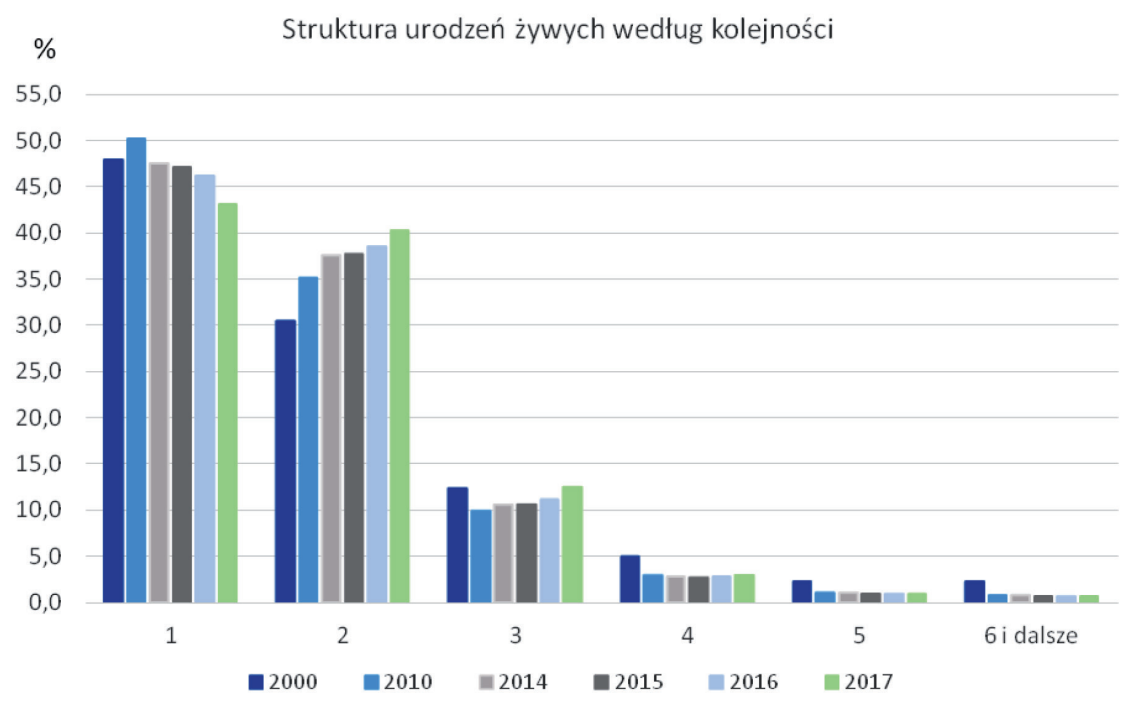

Wiele obserwacji wskazuje na systematyczne zbliżanie się wzorców kształtowania się procesów demograficznych w miastach i na wsi. Nadal odnotowujemy wyższą dzietność kobiet na wsi i wyższą przeciętną kolejność urodzenia dziecka u matki, natomiast upodabniają się wzorce zachowań prokreacyjnych i prorodzinnych w obu populacjach oraz podobnie kształtują się zmiany w strukturze urodzeń według kolejności.

Ocena sytuacji demograficznej kraju musi uwzględniać wieloletnie trendy wszystkich jej składowych, jak również zmiany zachowań będące m.in. następstwem zmian kulturowych oraz działań w sferze polityki społecznej. Można przypuszczać, że notowany w 2016 i w 2017 roku wzrost liczby urodzeń stanowi skumulowany efekt działań prorodzinnych państwa oraz poprawy sytuacji na rynku pracy, które wspierają realizację odłożonych wcześniej decyzji prokreacyjnych. Należy jednak mieć na uwadze to, że możliwości silnego wzrostu dzietności będą coraz bardziej ograniczone przez zmniejszającą się liczbę potencjalnych przyszłych matek. 
Bibliografia:

Baza Demografia, www.stat.gov.pl.

Rocznik Demograficzny 2017, Roczniki Branżowe, Główny Urząd Statystyczny, Warszawa 2017.

Sytuacja demograficzna Polski do 2017 r. Urodzenia i dzietność. Analizy statystyczne, Główny Urząd Statystyczny, Warszawa 2018. 